\title{
Kuantifikasi opasitas hasil radiografi mesin $\mathrm{x}$-ray analog
}

\author{
Dwi Utari Rahmiati ${ }^{1, *}$, Gunanti $^{2}$, Riki Siswandi ${ }^{2}$, Mokhamad Fakhrul Ulum $^{2, \dagger}$ \\ ${ }^{1}$ Program Studi Kedokteran Hewan, Universitas Padjadjaran, Bandung \\ ${ }^{2}$ Departemen Klinik, Reproduksi, dan Patologi, Fakultas Kedokteran Hewan, Institut Pertanian Bogor, Bogor
}

\begin{abstract}
ABSTRAK: Citra radiografi suatu objek yang diperoleh dari mesin x-ray analog adalah berupa film yang telah tercetak sebagai suatu gambar dengan gradasi warna hitam, abu dan putih yang disebut sebagai opasitas. Penilaian perubahan opasitas pada film hasil radiografi analog dilakukan dengan bantuan lampu illuminator untuk menampilkan citra dari objek. Identifikasi perubahan opasitas suatu objek dilakukan oleh dokter hewan secara kualitatif dan bersifat sangat subjektif. Tulisan ini menyajikan teknik kuantifikasi sederhana dalam menilai opasitas citra radiografi analog menjadi hasil yang lebih objektif untuk mengurangi subjektifitas. Film radiografi analog yang telah diperoleh selanjutnya diubah menjadi digital secara fotografi menggunakan kamera digital yang ada pada ponsel genggam. Fotografi citra dilakukan di ruangan gelap dengan bantuan lampu illuminator. Foto kemudian dipindahkan ke perangkat komputer untuk diolah dengan perangkat lunak ImageJ. Nilai opasitas suatu area terpilih ditentukan oleh densitas objek berupa gray value pada setiap pixel dalam rentang angka 0-255. Nilai nol untuk citra paling gelap berwarna hitam sebagai radiolucent, sedangkan nilai 255 untuk citra paling terang berwarna putih sebagai radiopaque.
\end{abstract}

Kata kunci:

densitas, gray value, opasitas, radiolucent, radiopaque

\section{- PENDAHULUAN}

Hasil radiografi yang diperoleh dari mesin x-ray analog adalah berupa film yang telah tercetak dalam gambar radiografi dengan gradasi warna hitam, abu dan putih yang disebut sebagai opasitas (Thrall \& Widner 2013). Penilaian perubahan opasitas pada citra radiografi analog dapat dilakukan dengan bantuan lampu illuminator untuk menampilkan objek yang diambil gambarnya. Akan tetapi, kondisi ruangan dan lingkungan saat proses interpretasi dengan lampu illuminator sangat berpengaruh pada detail citra radiografi (Moshfeghi et al. 2015). Begitu pula jarak antara interpretator dengan illuminator juga turut berpengaruh (Thrall \& Widner 2013). Kondisi ruangan dan jarak yang bervariasi dapat menyebabkan ketidaksepahaman dalam proses interpretasi sebagai akibat dari respon sel kerucut dan batang pada mata pada kondisi gelap dan terang yang berbeda antar individu (Kawai et al. 2005). Nilai opasitas berupa derajat hitam, abu dan putih dapat menjadi petunjuk adanya kelainan pada objek yang berguna dalam proses penegakan diagnosa (Thrall \& Widner 2013).

Pengkodean warna untuk radiografi telah dikembangkan oleh Shi et al. (2002) berupa kode warna secara digital, untuk warna abu, merah, hijau dan biru dari skala 0 hingga 255 . Nilai ini dihasilkan melalui proses digitalisasi suatu gambar dua dimensi dalam bentuk cetak. Artikel ini menyajikan langkah sederhana dalam melakukan digitalisasi gambar radiografi analog disertai proses kuantifikasi data warna menggunakan perangkat lunak ImageJ untuk mengurangi subjektifitas interpretator terhadap opasitas suatu objek pada citra radiografi.

\section{MATERI DAN METODE}

Aplikasi CamScanner ${ }^{\circledR}$ pada telepon genggam dan perangkat lunak Image $J \circledR$ pada komputer sebagai perangkat pengolah data dari citra foto digital. Hasil radiografi analog berupa lembar film dicitrakan kembali dengan kamera digital pada telepon genggam menjadi foto digital. Proses digitalisasi film radiografi analog dilakukan di ruangan gelap dengan bantuan lampu illuminator dengan atau tanpa modifikasi untuk menampilkan objek pada film (Gambar 1). Bagian illuminator yang tidak digunakan, ditutup dengan karton hitam atau bahan tidak tembus cahaya. Kemudian alat ukur berupa penggaris disisipkan atau ditempelkan pada bagian atas film sebagai acuan standar ukuran dalam citra digital (Gambar 1).

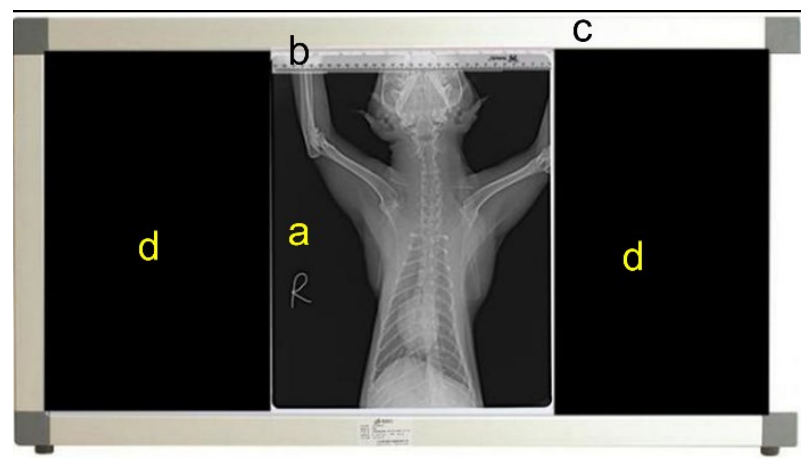

Gambar 1. Film radiografi (a) dan penggaris (b) pada lampu illuminator (c) dengan penutup karton hitam (d).

Diterima: 20-03-2020 | Direvisi: 17-04-2020 | Disetujui: 25-04-2020 (C) 2020 CC-BY-SA. Ini adalah artikel Open Access yang didistribusikan berdasarkan ketentuan dari Creative Commons Attribution ShareAlike 4.0 International License (https://creativecommons.org/licenses/by-sa/4.0/). 
Foto diambil menggunakan aplikasi CamScanner ${ }^{\circledR}$ pada telepon genggam dan disimpan dalam bentuk .jpg atau .jpeg. Foto .jpg difilter dengan mode gray pada aplikasi pengolah gambar. Foto digital berwarna gray dipindahkan ke perangkat keras komputer atau laptop untuk diolah lebih lanjut menggunakan perangkat lunak ImageJ ${ }^{\circledR}$.

Tahapan pengolahan gambar dengan perangkat lunak ImageJ adalah sebagai berikut;

1. Membuka gambar: pilih menu file lalu pilih menu open. Pilih gambar yang sudah dipindahkan dari CamScanner ${ }^{\circledR}$ dalam computer. Jika file gambar digital radiografi dilengkapi skala penggaris, maka hasil analisa lanjutan dapat menampilkan parameter ukuran (lanjut ke nomor 2). Namun jika tidak ada penggaris, maka hasil analisa hanya menampilkan gray value (lanjut ke nomor 4).

2. Membuat standar ukuran: pilih menu straight line kemudian arahkan ke bagian skala penggaris dan buat garis hingga ukuran $1 \mathrm{~cm}$ pada penggaris. Pilih menu analyze, kemudian pilih menu set scale. Akan tampil data dalam pixel, lengkapi known distance $=1$, pixel aspect $r a-$ tio $=1$, unit of lenght $=\mathrm{cm}$ atau $\mathrm{mm}$ (sesuai target analisis). Kemudian pilih OK.

3. Menambahkan skala pada gambar: pilih menu analyze, kemudian pilih menu tools dan pilih menu scale bar. Isi sesuai dengan kebutuhan tampilan. Pilih OK

4. Menambahkan parameter pengukuran: pilih menu analyze lalu, pilih set measurements, tandai pilihan kotak area, min \& max gray value, mean gray value dan nilai lainnya yang dibutuhkan. Pilih OK.

5. Melakukan kalibrasi dan pengukuran: pilih menu kotak atau elliptical, lalu buat drag dilokasi yang dinilai. Ukuran luas area (kotak/elliptical) harus sama untuk konsistensi dalam pengukuran, area yang telah dibuat dapat digeser dengan menekan tombol panah pada papan ketik sesuai posisi yang diukur. Ukuran area ukur disesuaikan dengan objek yang diukur agar tidak melebihi batas (Gambar 2).
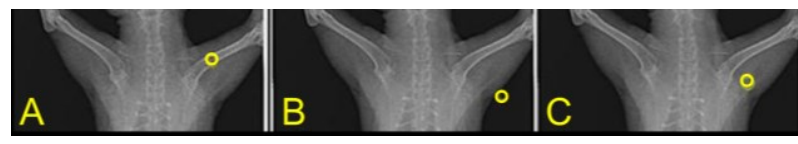

Gambar 2. Contoh pengukuran bagian objek lokal dengan bentuk Elliptical pada (a) tulang, (b) daerah tepi, dan (c) otot.

6. Menampilkan hasil pengukuran: pilih menu analyze, lalu pilih menu measurements. Hasil akan muncul sesuai parameter yang dipilih (nomor 4) yaitu: luas area, mean gray value, min gray dan max gray value (Gambar 3).

\begin{tabular}{|c|c|c|c|c|c|c|c|}
\hline \multicolumn{5}{|c|}{$£$ Results } & - & $\square$ & $\times$ \\
\hline \multicolumn{8}{|c|}{ File Edit Font } \\
\hline & Area & Mean & Min & Max & & & $\wedge$ \\
\hline 1 & 3684 & 116.390 & 68 & 211 & & & \\
\hline 2 & 0.133 & 25.324 & 21 & 28 & & & \\
\hline 3 & 0.153 & 99.508 & 58 & 148 & & & \\
\hline
\end{tabular}

Gambar 3. Hasil pengukuran gray value dengan ImageJ $($.

\section{- HASIL DAN PEMBAHASAN}

Gray value ditampilkan pada kolom Mean (mean gray value). Gray value pada setiap pixel memiliki rentang 0-255. Nilai 0 untuk radioluscent, sedangkan nilai 255 untuk radiopaque (Geiger et al. 2016). Gray value pada lokasi pertama yaitu tulang menunjukkan nilai 116.390. Gray value pada lokasi kedua yaitu latar film atau udara menunjukkan nilai 25.324. Gray value pada lokasi ketiga yaitu otot menunjukkan nilai 99.508. Hal ini menunjukkan bahwa semakin besar gray value maka warna objek yang diukur memiliki warna semakin putih. Hal ini sesuai dengan skala warna pada Shi et al. (2002), 0 adalah nilai untuk warna hitam dan 255 adalah untuk warna putih. Semakin putih atau opaque maka menunjukkan densitas objek semakin besar.

Jaringan atau materi yang berbeda penyusunnya akan memiliki nilai absorbsi yang berbeda pula. Densitas dan absorbsi mempengaruhi radiopasitas, radiolusensi, densitas radiografi, dan derajat kehitaman film. Jika suatu material memiliki nilai absorbsi tinggi, maka jumlah foton yang diteruskan dari objek semakin rendah sehingga interaksi foton dengan emulsi film menurun (Thrall \& Widner 2013).

\section{- SIMPULAN}

Kuantifikasi hasil radiografi mesin x-ray analog secara objektif dapat dilakukan dengan mudah menggunakan kamera digital dan dilanjutkan dengan menilai gray value menggunakan perangkat lunak ImageJ. Hal ini dapat mengurangi adanya perbedaan persepsi antar interpretator dalam membaca citra radiografi analog.

\section{— INFORMASI PENULIS}

Penulis untuk Korespondensi

*DUR: dwi.utari@unpad.ac.id

Program Studi Kedokteran Hewan, Fakultas Kedokteran, Universitas Padjadjaran, Bandung

$\dagger$ MFU: ulum@ipb.ac.id

Depertemen Klinik, Reproduksi, dan Patologi, Fakultas Kedokteran. Institut Pertanian Bogor. Jl. Agatis Kampus IPB Dramaga Bogor 16680

\section{- PUSTAKA ACUAN}

Geiger M, Blem G, Ludwig A. 2016. Evaluation of imageJ for relative bone density measurement and clinical application. Journal of Oral Health and Craniofacial Science. 1(1):012-021.

Kawai T, Sato K, Yosue T. 2005. Effects of viewing conditions on the detection of contrast details on intraoral radiographs. Oral Radiology. 21(1): 23-29.

Moshfeghi M, Shahbazian M, Sajadi SS, Sajadi S, Ansari H. 2015. Effect of different viewing conditions on radiographic interpretation. Journal of dentistry (Tehran, Iran). 12(11):853-858.

Shi XQ, Sallstrom P, Welander U. 2002. A color coding for radiographic images. Image and Vision Computing. 20(11): 761-767.

Thrall DE, Widner WR. 2013. Chapter I: Radiation Protection and Physics of Diagnostic Radiology, Di dalam Textbook of Veterinary Diagnostic Radiology. 6th ed. Carolina (US): Elsevier Inc. 
